\title{
MICE sebagai Wadah Kreatifitas Supporter Bonek pada Rancangan Pusat Bisnis Gelora Bung Tomo
}

\author{
Abdul Aziz ${ }^{1}$, Esty Poedjioetami ${ }^{2}$, Failasuf Herman Hendra ${ }^{3}$ \\ 1,2,3Jurusan Arsitektur, Fakultas Teknik Sipil dan Perencanaan, \\ Institut Teknologi Adhi Tama Surabaya \\ Email: ${ }^{1}$ abdur025@gmail.com
}

\begin{abstract}
MICE (meeting, incentive, convention, and exhibition) is considered from several aspects that have not been fulfilled in the Bung Tomo Gelora Area, namely the eradication of supporters outside the stadium that has run out of tickets, the lack of tenant sellers so that Traders roam along the road, and the routine agenda by Persebaya Officials that have not been encompassed so as to borrow another very poor place far. With the attractiveness of the Business Center, supporters can have a nobar place near the stadium despite running out of tickets, Tenants arranged for the economic survival of traders, as well as a forum for creativity between supporters and the Official Persebaya in the form of MICE. Case and field research methods with descriptive approaches are used to plan the creativity of the Business Center in the Bung Tomo Gelora Area. MICE (meeting, incentive, convention, and exhibition) was designed with a macro concept of spirit to produce building spirits that support sustainable architecture. Macro-concept Spirit has 3 micro-concepts, namely; Interactive as a land arrangement resulting in a container of many interactions, Symbolic as a form of order to produce an iconic crocodile tail and Communicative as a spatial arrangement so that a large area of land is produced to communicate the supportability of Bonek's supporters.
\end{abstract}

Keywords: Sustainable Architecture, Business Center; Supporter of Persebaya; MICE

\begin{abstract}
Abstrak. MICE (meeting, incentive, convention, and exhibition) dipertimbangkan dari beberapa aspek yang belum terpenuhi di Kawasan Gelora Bung Tomo, yaitu membeludaknya supporter di luar stadion yang kehabisan tiket, minimnya tenant penjual sehingga Pedagang berkeliaran di sepanjang jalan, dan agenda rutinan oleh Official Persebaya yang belum terwadahi sehingga meminjam tempat lain yang sangat jauh. Dengan adanya daya tarik Pusat Bisnis, supporter dapat memiliki tempat nobar dekat stadion walau kehabisan tiket, Tenants yang tertata demi kelangsungan ekonomi pedagang, serta wadah untuk berkreatifitas antara supporter dengan pihak Official Persebaya dalam bentuk MICE (meeting, incentive, convention, and exhibition). Metode penelitian kasus dan lapangan dengan pendekatan deskriptif digunakan untuk merencanakan wadah kreatifitas Pusat Bisnis di Kawasan Gelora Bung Tomo. MICE dirancang dengan makro konsep spirit sehingga dihasilkan ruh bangunan yang mendukung sustainable architecture. Makro-konsep Spirit memiliki 3 mikro-konsep, yakni; Interaktif sebagai tatanan lahan sehingga dihasilkan wadah banyak interaksi, Simbolis sebagai tatanan bentuk sehingga dihasilkan ikonik ekor buaya dan Komunikatif sebagai tatanan ruang sehingga dihasilkan lahan yang luas untuk mengkomunikasikan kratifitas supporter Bonek.
\end{abstract}

Kata kunci: Sustainable Architecture, Pusat Bisnis; Supporter Persebaya; MICE

\section{Pendahuluan}

Penyelenggaraan pertemuan, perjalanan insentif, konvensi, dan pameran (meeting, incentive, convention, and exhibition) yang dalam hal ini selanjutnya disebut MICE merupakan salah satu industri penggerak bagi pengembangan destinasi pariwisata yang berdaya saing. Industri MICE memberikan dampak dalam meningkatkan pendapatan, memperluas lapangan dan kesempatan kerja serta mendorong masuknya investasi. (Permenparekraf No. 5 Th. 2017, p.6). 
Bonek dikenal dengan nama Bondo (Modal), Nekat \& Kreatif (Azrul Ananda,2017). Bonek merupakan supporter klub sepakbola Persebaya Surabaya. Kreatifitas supporter bonek berupa banyak hal seperti, yel-yel, koreografi, atribut supporter. Tak hanya kreatifitas supporter, Manajemen Persebaya memiliki agenda rutinan untuk mendukung kreatifitas Persebaya, seperti; Meet $n$ Greet antara pemain dengan supporter, Greenforce Run (Kegiatan serupa jalan sehat), acara amal yang melibatkan manajemen \& supporter,

Perancangan Pusat Bisnis di kawasan Gelora Bung Tomo. Dibutuhkan untuk mewadahi kreatifitas supporter dan manajemen Persebaya yang mendukung penerapan Sustainable pada Pusat Bisnis tersebut. Tak hanya menghadirkan wadah kreatifitas, Pusat Bisnis memiliki hunian sebagai tempat tinggal sementara bagi pemain, manajemen \& supporter luar kota.

\subsection{Tinjauan Pustaka}

Menurut James Steele, Sustainable Architecture adalah Arsitektur yang memenuhi kebutuhan saat ini, tanpa membahayakan kemampuan generasi mendatang, dalam memenuhi kebutuhan mereka sendiri. Kebutuhan itu berbeda dari satu masyarakat ke masyarakat lain, dari satu kawasan ke kawasan lain dan paling baik bila ditentukan oleh masyarakat terkait. Kerusakan hubungan antar lingkungan banyak disebabkan oleh pengembangan bangunan yang hanya jangka pendek dan tidak sesuai dan tepat sasaran, perlunya pengembangan jangka panjang sangat penting dalam konsekuensi perkembangan ekonomi skala kota. (Pitts, 2004, p.9)

Rekayasa arsitektur berkelanjutan merupakan konsekuensi dari komitmen internasional tentang pembangunan berkelanjutan karena arsitektur berkaitan erat dan fokus perhatiannya kepada faktor manusia dengan menitikberatkan pada pilar utama konsep pembangunan berkelanjutan yaitu aspek lingkungan binaan dengan pengembangan lingkungannya, di samping pilar pembangunan ekonomi dan sosial. (Supriyanta, 2018, p.3)

Usaha Penyelenggaraan Pertemuan, Insentif, Konvensi dan Pameran (Meeting, Incentive, Convention, Exhibition) yang selanjutnya disebut MICE adalah pemberian jasa bagi suatu pertemuan sekelompok orang, penyelenggaraan perjalanan bagi karyawan dan mitra usaha sebagai imbalan atas prestasinya, serta penyelenggaraan pameran dalam rangka penyebarluasan informasi dan promosi suatu barang dan jasa yang berskala nasional, regional, dan internasional. (Permenparekraf No.5 Th. 2017, p.8). Jenis kegiatan MICE antara lain: Gedung pertemuan, Convention, Tempat pameran, Gedung pertunjukan, galeri seni, dan sejenisnya. (Perwali Surabaya No. 52 Thn. 2017, p.37)

\subsection{Metode}

Penelitian ini menggunakan teknik penelitian kualitatif dengan jenis penelitian deskriptif, yang mana, teknik penelitian deskriptif sifat penelitian dipilih untuk menyajikan gambaran lengkap mengenai setting sosial atau dimaksudkan untuk eksplorasi dan klarifikasi mengenai suatu fenomena atau kenyataan sosial di kawasan Gelora Bung Tomo. Dalam penelitian ini yang diambil sebagai perencanaan dan perancangan adalah lahan kosong seluas 8 hektar di persimpangan Jl. Jawar Surabaya dan Jl. Gelora Bung Tomo.

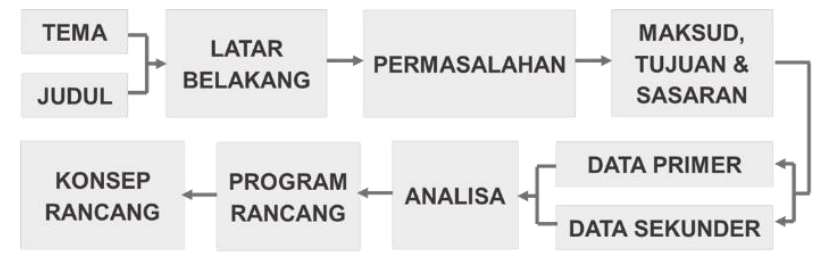

Gambar 1. Diagram alur pikir

\section{Pembahasan}

Tapak yang dipilih seluas 8 Ha berada di Kawasan Gelora Bung Tomo. Kawasan yang menjadi obyek perancangan ini berada di Kecamatan Benowo yang beralamat di Jl. Stadion Gelora Bung tomo dan Jl. Jawar Surabaya. 
Berdasarkan hasil pengumpulan data lokasi didapatkan gambaran umum kawasan Gelora Bung Tomo, sebagai berikut:
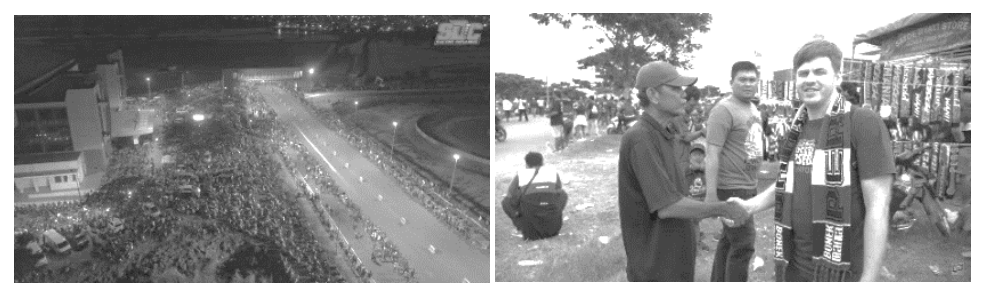

Gambar 2 (a) Parkiran dekat sirkuit GBT (b) Pedagang di Kawasan GBT

Sumber : (kiri) https://www.bikersnote.co.id/dituduh-jadikan-sirkuit-gelora-bung-tomo-sebagai-lahankeruk-rupiah-ini-jawaban-monohok-sdc, (kanan) https://www.youtube.com/watch?v=7tWe6OCsIe8
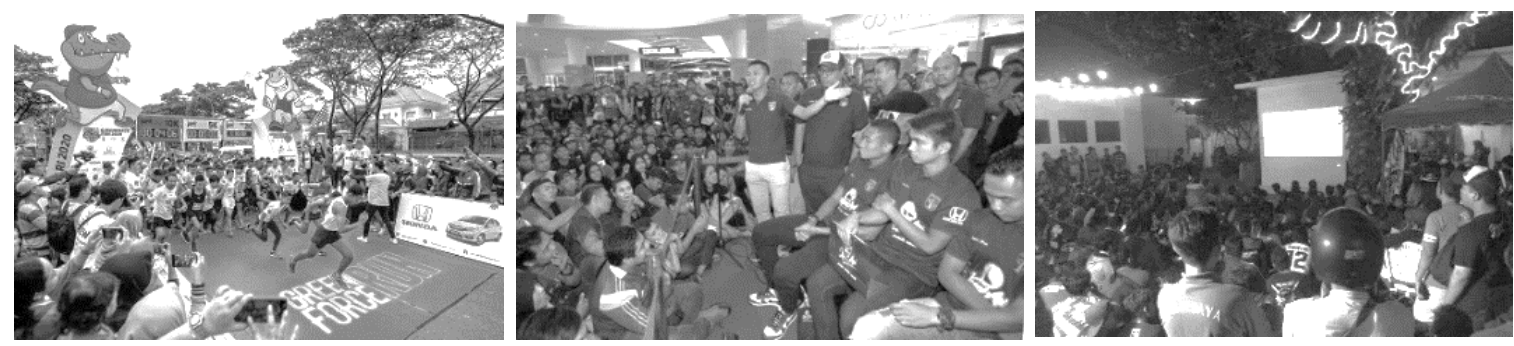

Gambar 3.a ; 3.b ; 3.c Greenforce Run di Ciputra Waterpark, Meet n Greet di Royal Plaza, Nonton bareng laga Persebaya di After Five Café

Sumber : (kiri) https://www.instagram.com/p/B8ZBH-VpjQw, (tengah) Angger Bondan/Jawa Pos, (kanan) Kadek Adi Arimbawa/Radar Bali

Pada Gambar 2.a dapat dilihat bahwa, belum adanya gedung parkir yang membuat parkiran tak beraturan dengan sirkulasi yang kurang jelas. Hal ini berdampak pada kemacetan sirkulasi kendaraan ketika menjelang pulang. Sedangkan pada Gambar 2.b dapat dilihat bahwa, pedagang liar yang berjejer di salah satu lajur utama menuju Stadion Gelora Bung Tomo menjadi background seorang Bule yang berwarga kenegaraan Indonesia sedang bersalaman dengan warga sekitar. Hal ini membuat jalan utama menjadi terblokade 1 sisi.

Dari hasil pengamatan interaksi sosial yang terjadi pada supporter di luar Stadion Gelora Bung Tomo, sebagai berikut: Gambar 3.a kiri dapat dilihat bahwa, Keseruan acara Greenforce Run. kiri. Hal ini berdampak pada kedekatan antara pihak manajemen Persebaya dengan pihak supporter di Ciputra Waterpark. kegiatan ini dapat menjadi rutinitas tahunan; Gambar 3.b tengah dapat dilihat bahwa, Official Persebaya mengadakan temu dengan para supporter di Royal Plaza. Hal ini bertujuan untuk mengenalkan lebih dekat antara supporter dengan pemain serta manajemen Persebaya. Kegiatan ini dapat menjadi rutinitas musiman karena ada bursa transfer pemain setiap 2x setiap tahun; dan Gambar 3.c kanan dapat dilihat bahwa, Nobar singkatan dari Nonton Bareng diantara kalangan Supporter yang kehabisan tiket terlihat menikmati keseruan di After Five Café. Hal ini bertujuan untuk menjadi solusi bagi Supporter yang tak bisa menyaksikan langsung di dalam Stadion. Kegiatan ini dapat menjadi rutinitas mingguan

Dari data yang diperoleh, maka dapat disimpulkan bahwa permasalahan utama dalam penerapan Sustainable pada rancangan Pusat Binsis adalah interaksi sosial antara manajemen Persebaya dengan Supporter sangatlah tinggi dan belum terakomodasi dengan baik. Sangat diperlukan pemahaman tentang kreatifitas supporter seperti nobar (Nonton bareng), Greenforce run, Meet $n$ Greet antara supporter dengan atlit, Pentas kreatifitas, Pameran karya, dll, Sehingga aktifitas ini dapat terwadahi menjadi fasilitas sosial demi menunjang penerapan Sustainable pada Pusat Bisnis di Kawasan Gelora Bung Tomo untuk jangka panjang.

Setelah melakukan pemahaman tentang karakter sosial khas supporter baik di Kawasan Gelora Bung Tomo ataupun di luarnya. Maka diperlukan analisis tapak terpilih untuk mengoptimalkan MICE di dalam Pusat Bisnis, sebagai berikut: 

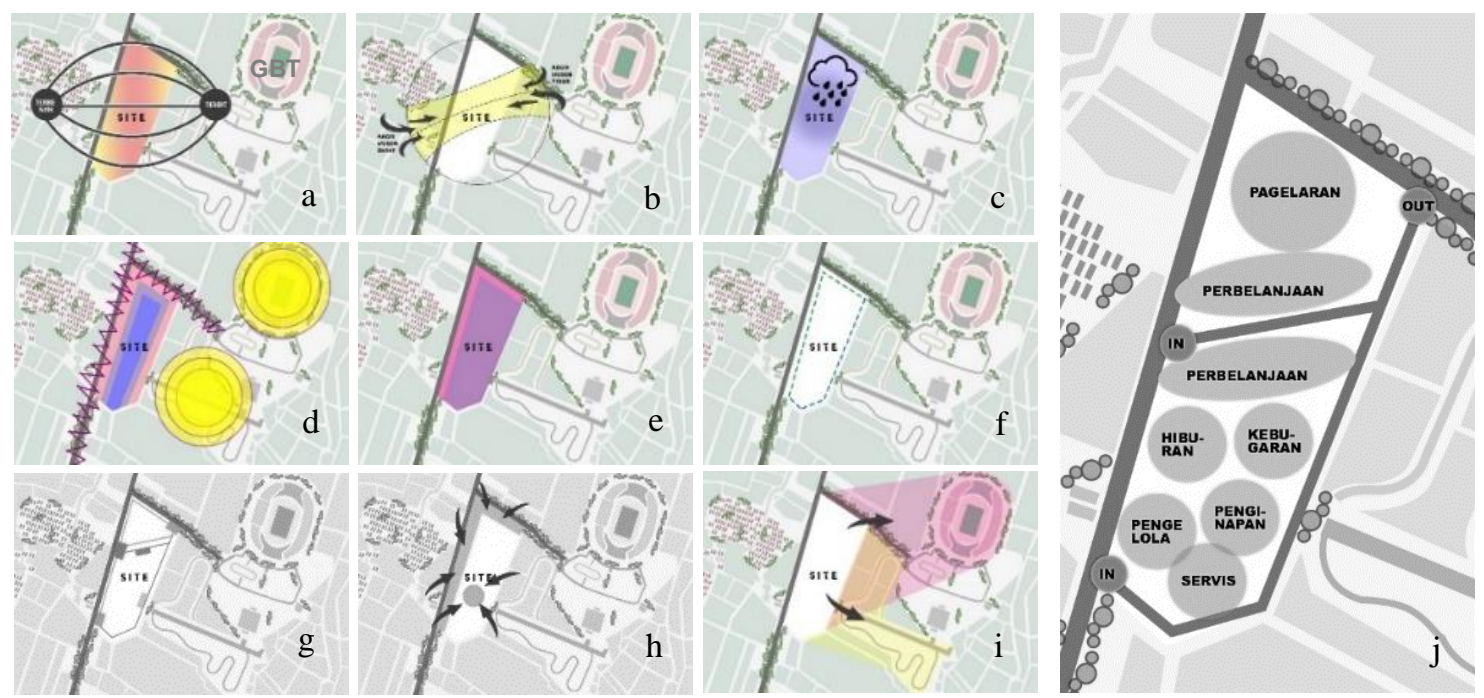

Gambar 4. Analisis matahari (a), angin (b), hujan (c), kebisingan (d), polusi (e), sepadan (f), sirkulasi (g), view to site (h), view from site (i) dan output Analisa tapak (j)

Sumber : Dokumentasi Pribadi

- Pada legenda a. dapat dilihat bahwa, Analisis Matahari: Diperlukan adanya penyerapan panas alami melalui roof graden, selain itu bisa juga dengan ditambahi kolam sebagai fungsi evaporasi.

- Pada legenda b. dapat dilihat bahwa, Analisis Angin: Massa bangunan akan diletakan menghalagi arah angin sehinga terjadi pembelokkan arah angin yang dapat dimanfaatkan sebagai penyejuk ruang terbuka.

- Pada legenda c. dapat dilihat bahwa, Analisis Hujan: diperlukan saluran drainase lingkungan supaya dapat menampung curah hujan di beberapa sisi yang sulit dijangkau.

- Pada legenda d. dapat dilihat bahwa, Analisis Kebisingan: Perlu adanya akustik alami sebagai peredam berupa tanaman di sepanjang sisi Timur, Utara dan Barat pada tapak

- Pada legenda e. dapat dilihat bahwa, Analisis polusi: Diperlukan adanya tanaman di area yang mengitari tapak untuk meminimalisasi polusi udara yang menuju ke dalam tapak.

- Pada legenda f. dapat dilihat bahwa, Analisis Sepadan: Garis GSB menurut Perwali Surabaya No. 52 Thn. 2017, menunujukkan bahwa area yang berdekatan dengan jalan 20 Meter memiliki GSB menghadap muka jalan sebesar 8 Meter dan GSB tidak menghadap muka jalan sebesar 6 meter.

- Pada legenda g. dapat dilihat bahwa, Analisis Sirkulasi: ME berada di arah Barat karena mudah dikenali dari luar, kemudian melewati Drop Area yang ditandai lalu bisa masuk di parkiran basement atau bisa langsung keluar melalui SE yang berada di sebelah utara. Sirkulasi Servis sengaja ditempatkan di area yang jarang terjangkau berada di sisi selatan dan timur bangunan yang bisa diakses mobil muatan juga mobil pemadam kebakaran. Loading dock berada di area timur bersebelahan dengan sirkulasi servis.

- Pada legenda h. dapat dilihat bahwa, Analisis View to: View ke Pusat Bisnis terdiri dari arah ke bangunan highrise (Lingkaran) dan arah ke bangunan midrise (Persegi panjang)

- Pada legenda i. dapat dilihat bahwa, Analisis View from Site: Site view Gelora Bung Tomo berada di arah Timur Laut dan view berada di arah tenggara. Adapun zona yang terdampak berada di sisi utara dan timur.

- Pada legenda j. dapat dilihat bahwa, Output Analisis tapak: MICE berada di bagian Utara jalan pemisah, sebab area ini berdekatan langsung dengan kepadatan massa supporter di jalan Stadion GBT dan jalan Jawar Surabaya. Di dalam MICE terdiri dari Pagelaran dan Perbelanjaan. 


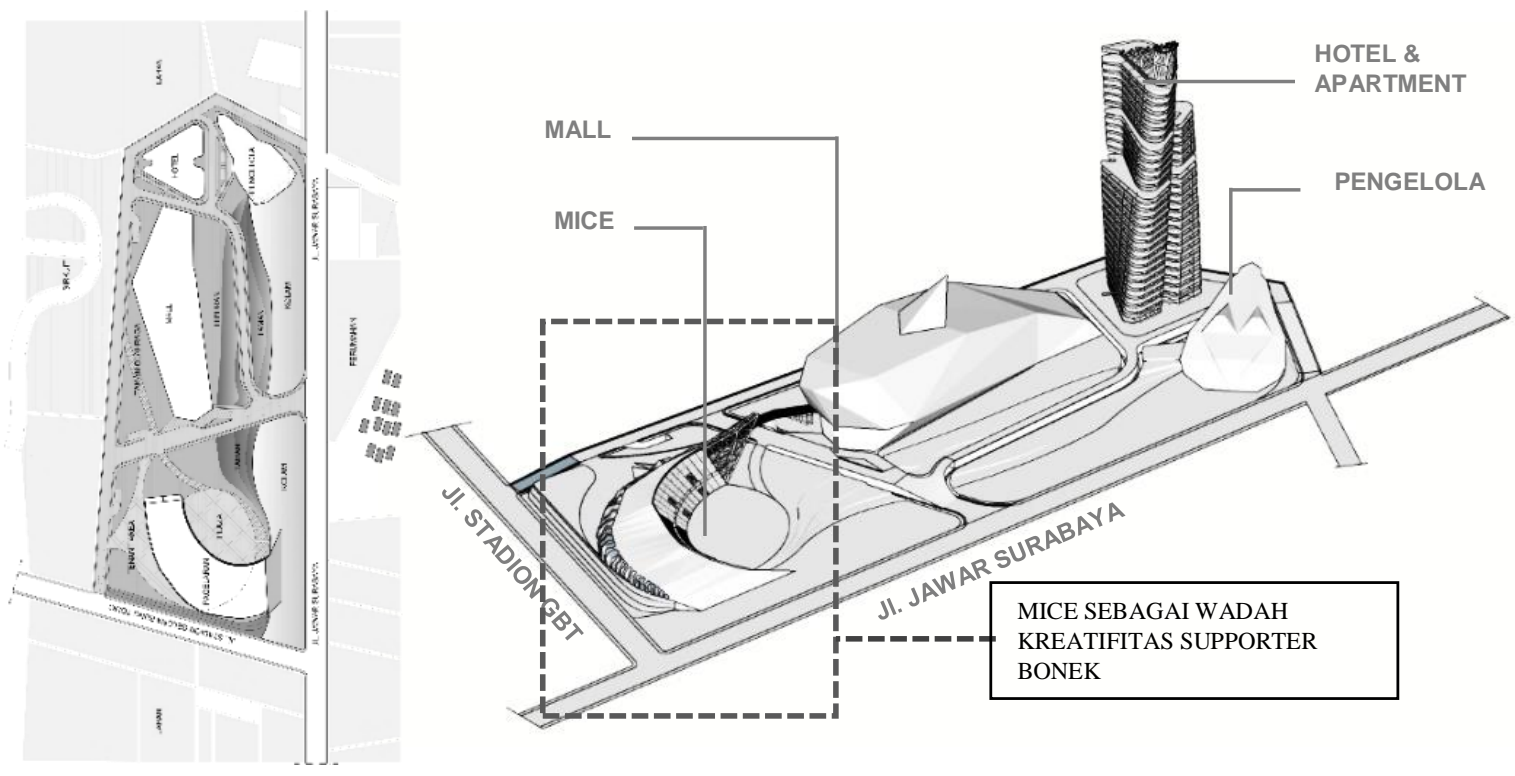

\section{Gambar 5.a \& 5.b Blokplan \& 3D Perspektif Tatanan Lahan Sumber : Dokumentasi Pribadi}

Pada Gambar 5.b Sustainable architecture dipilih sebagai tema dikarenakan ada 3 aspek penting yang mendasari rancangan MICE, seperti: aspek sosial yang melibatkan Bonek, pedagang, Official Club; aspek ekonomi yang meliputi Penyewaan Gedung indoor MICE \& tenant; dan aspek lingkungan yang meliputi kolam sebagai evaporasi \& penampungan hujan sementara. Sinergi 3 Aspek inilah yang membangun arsitektur keberlanjutan.

Spirit dipilih sebagai makro konsep Pusat Bisnis terutama fasilitas MICE dikarenakan semangat para pendukung Persebaya yang luar biasa, hal itu dibuktikan dengan slogan, "SALAM SATU NYALI! WANI!". Hal ini pula yang mendasari bahwa MICE dibangun untuk menaikkan semangat dan gairah dalam mendukung kebanggaannya. Spirit pada MICE juga berarti roh pada pusat bisnis di Kawasan Gelora Bung Tomo, disebabkan adanya aktifitas rutinan sehingga proyek ini memiliki kehidupan yang Sustainable.

Sehingga dihasilkan rancangan MICE (Meeting, Incentive, Convention, Exhibition) sebagaimaa pada gambar 6. Pada gambar 5. Interaktif dipilih sebagai mikro konsep tatanan lahan MICE karena beberapa aspek, seperti posisi fasilitas MICE yang berbatasan dengan persimpangan jalan. Interaksi yang ada di Jl. Stadion GBT seperti jual beli atribut supporter oleh pedagang liar supaya dapat menempati area tenant (a). sedangkan supporter yang kehabisan tiket dapat menempati plaza \& tribun (c), Adapun area indoor (b) digunakan sebagai acara meet \& greet atau pameran kreatifitas supporter Persebaya. Serta ada wahana air (e) selain untuk wisata juga untuk evaporasi supaya kelembaban tapak dapat terjaga. 


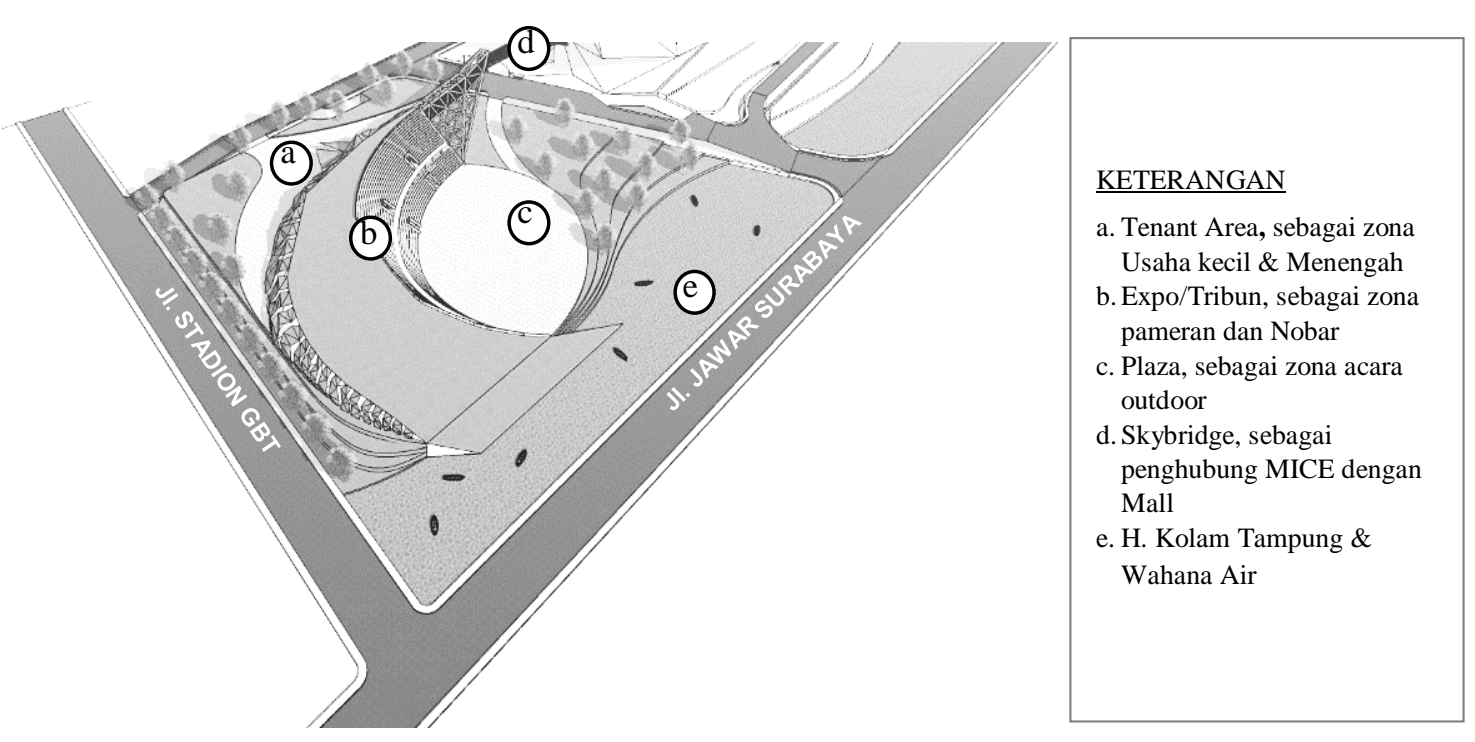

Gambar 6. Perspektif MICE pada Tatanan Lahan Pusat Bisnis Sumber : Dokumentasi Pribadi
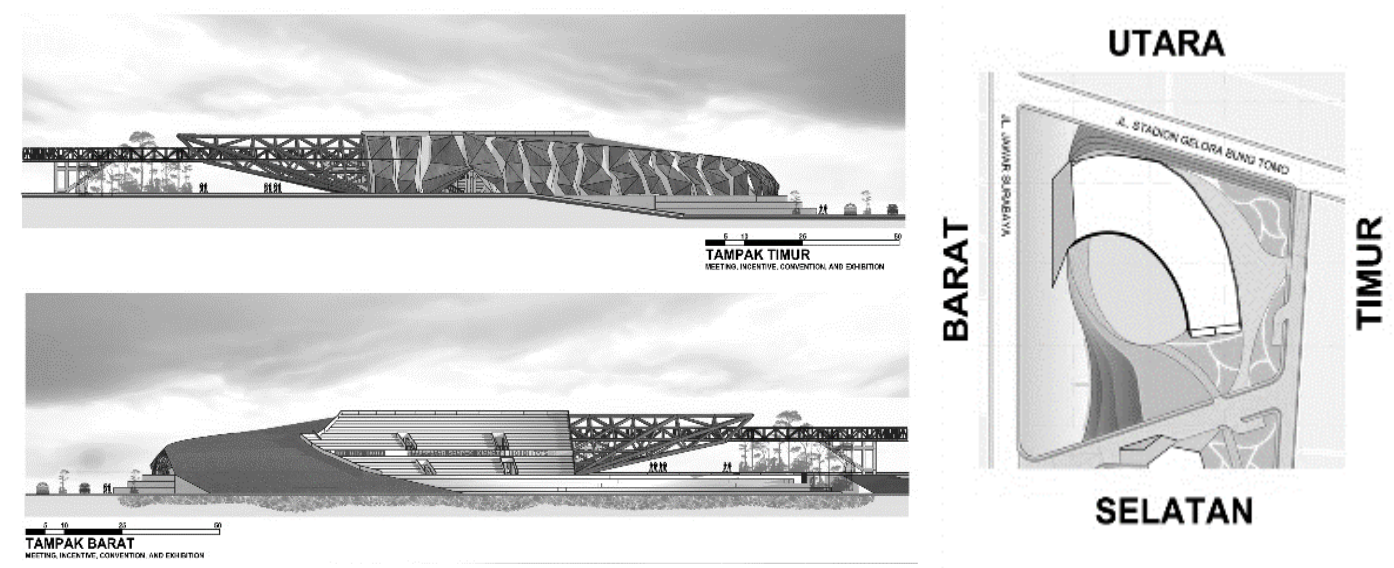

\section{Gambar 7. Tampak \& Keyplan MICE pada Tatanan Lahan Pusat Bisnis \\ Sumber : Dokumentasi Pribadi}

Pada gambar 7. Simbolis dipilih sebagai mikro konsep tatanan bentuk MICE karena beberapa aspek, seperti Historis simbol buaya sebagai maskot Persebaya. Pada pengaplikasiannya terlihat dari ekor buaya yang melengkung sebagai tribun dengan akhiran ekor sebagai jembatan menuju fasilitas perbelanjaan (mall). Fasad conwood dipilih sebagai irama yang mengingatkan pada gerigi ekor buaya. Dengan simbolis, dapat meningkatkan spirit dalam meengaplikasikan Sustainable. 


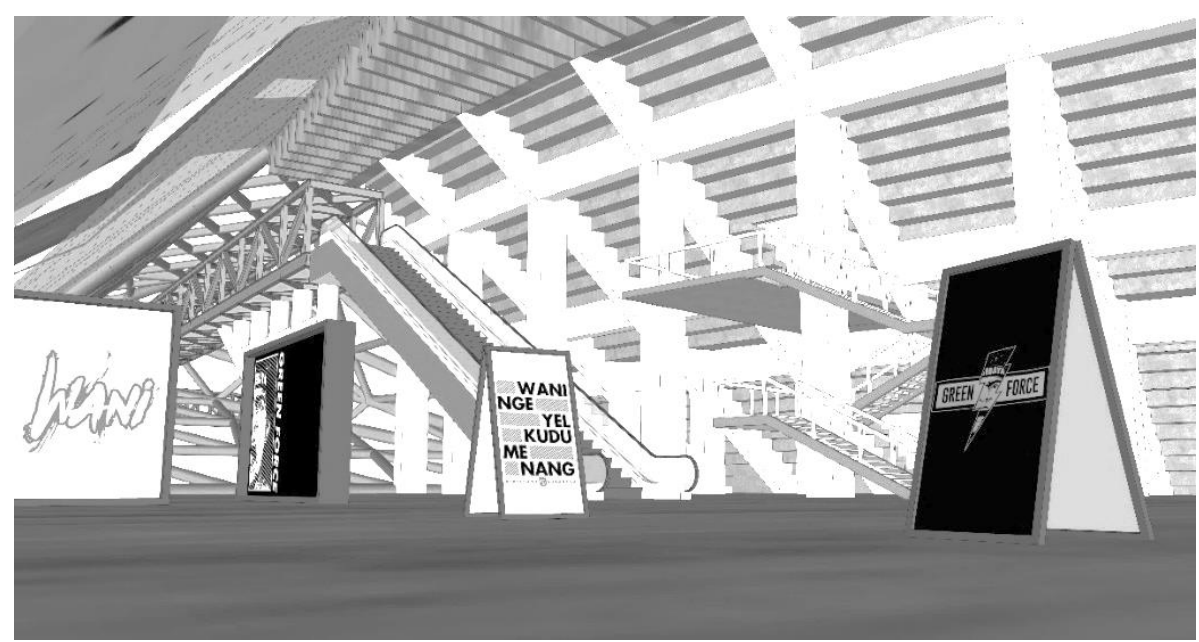

Gambar 8. Interior MICE

Sumber : Dokumentasi Pribadi

Pada Gambar 8. Komunikatif dipilih sebagai mikro konsep tatanan ruang MICE karena beberapa aspek, seperti area area yang dibuat luas sehingga Event Organizer bisa lebih leluasa dalam mengkomunikasikan ruang supaya dapat mendukung spirit yang terjadi pada Supporter Persebaya.

\section{Kesimpulan}

Dari pembahasan yang telah dilakukan, dapat disimpulkan bahwa penyelesaian kebutuhan kreatifitas supporter yang berada di Kawasan Gelora Bung Tomo adalah dengan menghadirkan MICE di dalam pusat Bisnis sebagai upaya untuk mewadahi kreatifitas supporter dalam mendukung tim kebanggaan. Kreatifitas supporter dimaksimalkan dengan penataan lahan yang dapat mewadahi interaksi antara lapisan masyarakat dengan pihak manajemen baik dari Official Club maupun dari pengelola Pusat Bisnis

\section{Referensi}

Ananda, Azrul. (2017). Bonek = Bondo, Nekat, dan Kreatif. Jawa Pos. [Diakses dari: https://www.jawapos.com/sepak-bola/sepak-bola-indonesia/21/03/2017/bonek-bondonekat-dan-kreatif/, 27 Juli 2015].

Peraturan Kementrian Pariwisata. (2017). Pedoman Destinasi penyelenggaraan Pertemuan, Perjalanan Insentif, Konvensi dan Pameran. Lembaran Kementrian Th. 2017, No.5. Sekretariat Kementrian. Jakarta. (hal. 6-8)

Peraturan Walikota Surabaya. (2017). Pedoman Teknis pengendalian Pemanfaatan Ruang dalam Rangka Pendirian Bangunan di Kota Surabaya. Lembaran Th. 2017, No.52. Sekretariat Hukum. Surabaya. (hal.37)

Pitts, Adrian. 2004. Planning and Design Strategies for Sustainability and Profit: Pragmatic sustainable design on building and urban scales. Oxford: Architectural Press. (hal.9)

Steele, James. (1997). Sustainable Architecture: Principle Paradigms Ana Case Studies. Edisi 8. New York: Mcgraw-Hill.

Supriyanta. (2018). Rekayasa Arsitektur Berkelanjutan berdasarkan Nilai Nilai Dasar Keislaman, Prosiding SEMNASTEK Fakultas Teknik Universitas Muhammadiyah Jakarta. (hal.9) 
